\title{
Globalization and the sustainable exploitation of scarce groundwater in coastal Peru
}

\author{
Jana Schwarz* and Erik Mathijs \\ KU Leuven, Department of Earth and Environmental Sciences, Division of Bioeconomics, \\ Celestijnenlaan200e, 3001 Leuven, Belgium \\ * Corresponding author. Email jana.schwarz@ kuleuven.be; Tel: +32 16372310.
}

This is a draft (pre-print) version of an article which appeared in the 'Journal of Cleaner Production'. Check the following website for the final, published version:

https://doi.org/10.1016/j.jclepro.2017.01.067

\begin{abstract}
Trade in agricultural and food products has increased sharply since the 1980s, but links and trade-offs between socio-economic benefits and environmental impacts of this trend have hardly been studied. The empirical analysis of this article focuses on the Ica province in Peru, where agricultural export production has led to huge economic growth and employment generation at the expense of unsustainable aquifer depletion. Building on the concept of ecosystem and societal metabolism (MuSIASEM), a model of the province including groundwater use, added value generation and employment creation is built. Absolute and relative differences between crop production for autoconsumption and national markets, and for export markets are assessed at different societal levels. Moreover, the impact of two land use scenarios aiming to reduce total groundwater extraction is explored. The analysis draws a picture of a system which is highly dependent on the use of natural resources. Export agriculture generates considerably more value added and employment while extracting more than five times more water from the aquifer than local crop production. The scenarios show that although being more efficient regarding intensive indicators, a reduction of groundwater use for export activities is indispensable to sustain environmentally sustainable agricultural production in the long run. Several policy measures aiming at mitigating groundwater depletion are discussed.
\end{abstract}

Keywords: globalization, groundwater, agricultural trade, sustainability, metabolic analysis, Peru 


\section{Introduction}

Globalization has increased rapidly during the past decades. Especially trade in agricultural and food products has increased tremendously since the 1980s. One major trend is the increasing inclusion of low- and middle-income countries in the trade of high-value products such as dairy products, fresh fruits and vegetables. Many studies point towards positive economic effects of increasing agricultural trade in developing countries, both at a national level (Dollar and Kraay, 2004) and at the household level (e.g., Aksoy and Beghin, 2005). These positive welfare effects occur through the participation of the local population in export value chains as contract farmers (e.g., Bellemare, 2012) or as laborers (Maertens et al., 2012), leading to higher incomes and hence poverty reduction.

A major environmental issue linked to increasing agricultural trade is the use of large volumes of water resources (Schwarz et al., 2015); a key element of sustainable development (WWAP, 2015). The agricultural sector uses $70 \%$ of the globally withdrawn freshwater (WWAP, 2014) and it has been estimated that $20 \%$ of the world's agricultural water use is for the cultivation of export products (Hoekstra and Mekonnen, 2012). A rapidly increasing share of irrigation water is abstracted from groundwater resources leading to increased agricultural productivity and a higher labour demand through year-round production. Moreover, regular water supply allows producers to shift towards the production of higher value products with higher economic water efficiency (Shah et al., 2007). However, positive socio-economic impacts are often linked to negative environmental consequences. Aquifers are often exploited under open access conditions leading to the overexploitation of most large aquifers in arid and semi-arid zones; most aquifers under water stress underlie major agricultural production areas (Famiglietti, 2014). In coastal areas, over-pumping can render aquifers useless due to salinity intrusion and while a period of low surface water supply can be compensated for in one year with high rainfall and runoff, aquifer depletion takes many decades to recover or may even be permanent (Gleeson et al., 2010). This can threaten socio-economic development through negative impacts on agricultural productivity and employment. Decreasing groundwater tables also lead to more inequality between smallholders, large farmers and the agroindustry due to increasing costs of groundwater pumping (Hoogesteger and Wester, 2015).

Most studies focus on either socio-economic implications of increasing globalization or on environmental impacts of trade with developing countries. Few studies simultaneously assess different sustainability aspects of globalization, one of the main reasons being the use of different metrics for assessing economic, environmental and social impacts. It has been shown that conclusions about the impact of agricultural trade differ when using monetary, nutritional and resource metrics (MacDonald 
et al., 2015). A joint analysis of economic and environmental aspects of trade has been carried out by Schwarz et al. (2015) who find that increasing high-value food exports from developing countries can be beneficial from a regional point of view due to high trade values and low water volumes but conclude that issues of water scarcity also need to be considered. Oglethorpe (2010) uses socioeconomic and environmental indicators and mathematical programming to depict interrelations between sustainability impacts of local, regional and national pork supply chain strategies. He finds that his approach can simplify complex decision situations and can be used to test sustainability impacts of strategic decisions.

In this study an accounting framework based on metabolic analysis is used - Multi-Scale Integrated Analysis of Societal and Ecosystem Metabolism (MuSIASEM) developed by Giampietro (2004) and refined by Giampietro et al (2009). It makes it possible to combine quantitative data on different sustainability aspects and to simultaneously analyze environmental, economic and social impacts of trade. Another advantage of the framework is the analysis of trade-offs between sustainability dimensions and the flexibility to compare indicators across different hierarchical scales such as the crop level, exports, and the whole agricultural sector. MuSIASEM can also be used for checking the feasibility and viability of scenarios. Much of the work on MuSIASEM has been theoretical, mainly focusing on food (Giampietro, 2004) and energy (Giampietro et al., 2009); and has recently been expanded to water (Madrid-López and Giampietro, 2015). Few empirical case studies have applied MuSIASEM to assess the water metabolism of agricultural systems. Cabello Villarejo and López Madrid (2014) analyze the impact of European water and agricultural policies on the Andarax river basin in Andalusia. Serrano-Tovar et al. (2014) include irrigation and soil water use for characterizing the metabolic pattern of Mauritius. Madrid-López et al. (2014) find that electricity and price subsidies are responsible for aquifer overdraft in Punjab.

The aim of this study is to explore the sustainability implications of increasing globalization in Peru. Specifically, a metabolic accounting framework is used to (i) analyze interactions between socioeconomic benefits of agricultural trade and the use of scarce groundwater resources and (ii) to compare export production with production for auto-consumption and national markets. With this approach the present study adds to the very scarce literature on sustainability trade-offs in agricultural supply chains. The focus on a main agricultural export region in South America is important as the continent is undergoing rapid changes in the volume and structure of trade while suffering from regional water scarcity (Mekonnen et al., 2015). Methodologically, a dynamic component is added to the scenario assessment with MuSIASEM by accounting for the fact that monetary flows are finite in case of 
depleted groundwater resources. The study may assist policy makers in the design of more sustainable environmental and economic policies, particularly regarding land use, water use and trade. Other researchers may use the same approach for implementing similar studies in other regions.

\section{The research area}

The empirical analysis focuses on Peru, a middle-income country which has experienced tremendous growth in the export of high-value products during the past few decades. Currently, Peru is the world's leading exporter of asparagus and exports of grapes have increased seventy-fivefold between 2000 and 2013 (FAO, 2015). This increase can be linked to a bundle of neoliberal national policies that have been implemented in the early 1990s (Schwarz et al., 2016). Production and processing activities are located in desert areas along the Pacific coast, an area that contains only $1.8 \%$ of the national freshwater resources but hosts around $63 \%$ of the country's population (MINAGRI et al., 2015). Specifically, the situation in the Ica province is assessed; the largest of five provinces of the Ica region located around $300 \mathrm{~km}$ south of Lima. The region produces nearly one third of Peru's horticultural and fruit exports, mostly destined to the US and the European market (Oré et al., 2012). In the Ica province the area devoted to the cultivation of export crops has tripled between 1997 and 2013, from approximately 7,400 ha to more than 22,000 ha (Figure 1). The largest share of this increase is due to the boom of asparagus cultivation, covering more than 10,000 ha in 2013. Other important export products are table grapes, onions and avocadoes. The production of crops for the national market and for auto-consumption such as corn, beans and potatoes has been relatively stable during the same period, with a harvested area of around 5,000 ha/y.

Figure 1: Harvested area of major export and local crops in the Ica province, 1997-2013

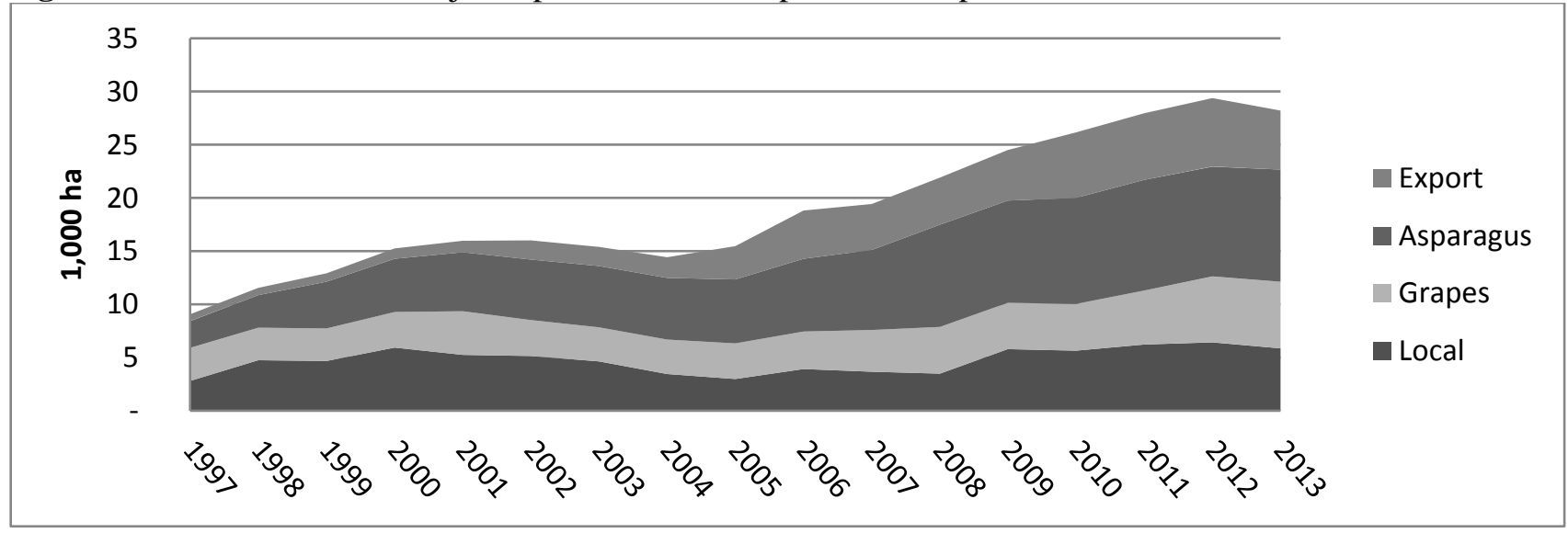

Note: Export crops include capsicum, artichoke, avocado, onion, citrus fruits. Local crops include corn, bean, chick pea, cotton, potato, mango. 
(Source: Dirección Regional Agraria de Ica, 2014)

The strong increase in the cultivation and processing of export products contributes to employment generation; nearly every fifth job in Ica is linked to agricultural production (Velazco and Velazco, 2012). Most of this employment is low-skilled and seasonal. Specific labour laws for non-traditional export companies (Decree Law 22342) and the agricultural export sector (Agricultural Sector Promotion Law 27360) give companies the right to indefinitely employ workers on short-term contracts and provide a special labour regime for agricultural workers in export-oriented nontraditional agri-food companies (Schuster and Maertens, 2016). This includes lower wages and less annual leave than in the general labour regime.

While there are positive effects of increasing agri-food trade on economic growth and employment, agricultural production has detrimental effects on the local water resources. Ica is located in a desert area almost devoid of rainfall, with an average annual precipitation of only $25.5 \mathrm{~mm}$. Around $88 \%$ of the total water used in the province comes from groundwater resources and $12 \%$ is surface water (own estimation based on ANA, 2015 and personal communication with ANA, 2016). Surface water originates from two main sources. First, the Ica River is characterized by very scarce and irregular water flow. The river originates in the Andes and only carries water during the summer months, between November/December and March/April. Second, from September to October, irrigation water comes from the Choclococha system, a regulated network of storage lakes and channels which divert water from the highlands to the Ica River. Most agricultural production, especially export production relies on groundwater resources extracted from the Ica-Villacurí aquifer. It is the biggest aquifer in Peru representing $40 \%$ of the national available groundwater resources (Oré et al., 2012).

The Ica-Villacurí aquifer underlies the Ica province. Estimated extraction rates have increased during the past decade, from $325 \mathrm{hm}^{3}$ in 1967/1968 to more than $500 \mathrm{hm}^{3}$ in 2009 (Figure 2), a volume equal to 200,000 Olympic swimming pools. Figures are shown separately for the Ica valley, where agricultural products have been cultivated historically by small and medium sized producers and the Villacurí pampas, where agro-export companies have settled and desert land has been converted into agricultural land. There are no surface water resources in the Villacurí pampas and the entire production depends on groundwater extraction which has more than tripled between 1968 and 2009. This has led to a steady decline of the groundwater table with up to $1.5 \mathrm{~m} / \mathrm{y}$ (ANA, 2012a). 
Figure 2: Evolution of groundwater extraction in the Ica valley and the Villacurí pampas $\left(\mathrm{hm}^{3}\right)$

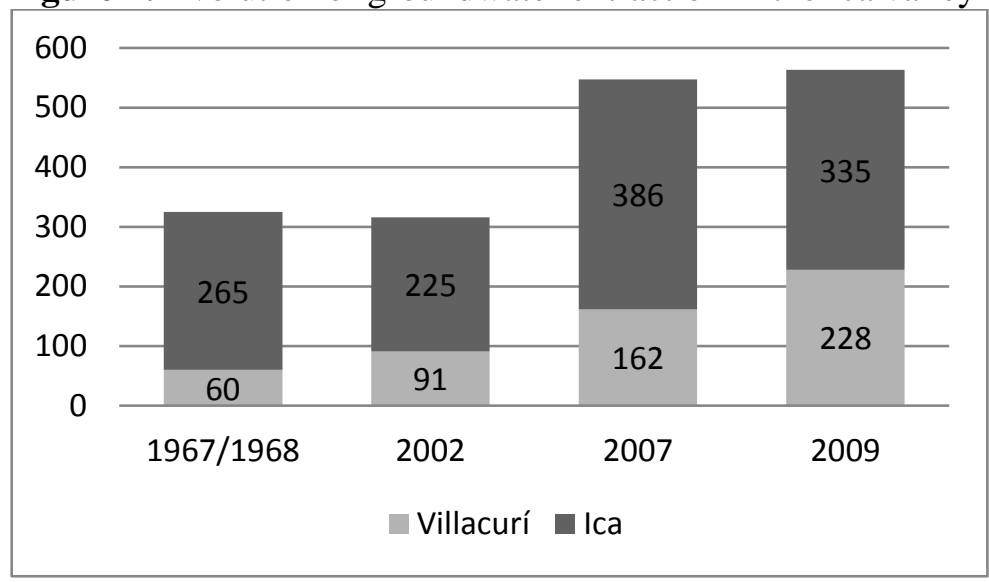

(Source: ANA, 2012a)

Based on numerical modelling the ANA has estimated that the maximum sustainable volume of annual water extraction from the Ica aquifer is $189 \mathrm{hm}^{3}$ (Table 1). The exploitable water volume in Villacurí has been estimated by the ANA based on the water flux from the Ica aquifer. Comparing these figures with the volumes of gross exploitation in 2013 it becomes clear that water extraction exceeds the exploitable water volume by more than $150 \mathrm{hm}^{3} / \mathrm{y}$ in both the Ica valley and the Villacurí pampas.

Table 1: Exploitable groundwater resources and overexploitation in $2013\left(\mathrm{hm}^{3} / \mathrm{y}\right)$

\begin{tabular}{llll} 
Aquifer & $\begin{array}{l}\text { Exploitable water } \\
\text { volume }\end{array}$ & Gross exploitation & Overexploitation \\
\hline Ica & 189 & 221 & -32 \\
Villacurí & 63 & 188 & -125 \\
\hline Total & 252 & 409 & -157 \\
\hline
\end{tabular}

(Source: ANA, 2012a, 2014)

Groundwater overexploitation does not only have negative repercussions on small farmers and domestic water users in the region (Hepworth et al., 2010), but also on the export sector itself. It has been estimated that within 10 years, $76 \%$ of the cultivated area in the Ica valley and $100 \%$ of the cultivated area in Villacurí will be affected by severe water shortage (ANA, s.d.). To respond to the imminent problem of aquifer depletion the ANA has introduced a ban on the perforation of new wells which also forbids making changes to existing wells (e.g., increasing the depth or diameter) in the catchment area of the aquifer. This ban has been ratified in 2011. The ANA also tries to advance the authorization process of wells as $74 \%$ of the wells in the province are still not licensed (ANA, 2014) 
and many do not count with a flow meter, complicating the monitoring of exploited groundwater volumes.

In contrast to these demand side measures, there are also plans to increase water supply through diverting water from the highlands and the Pisco River towards the Ica valley and the Villacurí pampas. These projects have fuelled conflicts between regional governments, the export sector and small farmers in the highlands (Oré et al., 2012) and it is not yet clear at what time additional water supplies will be available in the province. The focus of the current study is therefore on the groundwater demand side only.

\section{Method}

The analysis is based on the MuSIASEM framework developed by Giampietro (2004) and its conceptual adaptation focusing on water resources - the water metabolism (Madrid-Lopez and Giampietro, 2015). MuSIASEM is an accounting approach that can be used to characterize the metabolism of socio-economic systems, their interaction with the ecosystem and to assess the viability and feasibility of scenarios. It builds on several concepts from Bioeconomics and Complex System Theory (Giampietro et al., 2014). The strength of MuSIASEM is the integration of quantitative information from different sources and models across sustainability dimensions and scales of analysis.

The studied system is subdivided into six different hierarchically nested levels of analysis (Figure 3). The highest level (n) is the province of Ica which coincides with the area of the Ica-Villacurí aquifer. Within the province, people are either engaged in the paid work sector or in the household (n-1), which includes activities such as leisure, sleeping and unpaid work. The groundwater-based agricultural sector (n-2) builds the focus of the analysis; it includes agricultural production on the field as well as processing and packaging activities (n-3). The latter are included in the analysis as they make up a large part of the activities related to exports. At level n-4 the agricultural sector is further subclassified into agricultural production for auto-consumption and the national market, and export agriculture. A total of 38 crops grown in the province are considered (n-5) and differentiation between local and export agriculture is based on the main use of crops. For most crops in the Ica province this classification is relatively straightforward and has been confirmed by experts. 
Figure 3: Hierarchically nested levels of analysis

$\mathrm{n}$

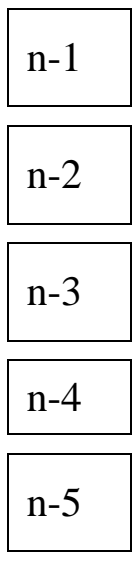

Ica province

Paid work (PW)

Households (HH)

Note: The size of the different levels is not relative to their importance.

In MuSIASEM a distinction is made between fund and flow elements. Funds are elements that are used by the system but their main characteristics do not change during the analysis. For instance, human activity (labour) is used for agricultural production, but the same labour force is available before and after the analyzed process. Flow elements, on the other hand, are elements that either (i) enter the system but do not leave it in the same state such as irrigation water or fertilizer inputs or (ii) leave it, such as outputs that have been generated during the socio-economic process, e.g. crops that are sold on the market. In this study two fund elements, namely land use and human activity, and two flow variables, namely value added and groundwater use are considered.

Based on MuSIASEM a system of accounting is established, starting with vectors of crop characteristics $c_{i e}$ at level n-5, where $i$ indicates the crop and $e$ whether it is exported or not. In this study $c_{i e}$ includes groundwater use, employment and value added per ha. By multiplying $c_{i e}$ with a scalar $\lambda_{i}$ - the land use per crop $i$ - total groundwater use, employment and value added of groundwaterbased agriculture are obtained for each crop. For calculating the extensive variables at level n-2 - the agricultural sector - the values for all crops produced in the province are summed up:

$$
\sum_{i=1}^{n} c_{i e} \lambda_{i}
$$

At lower levels of analysis subgroups of crops are built. At n-4 crops are grouped according to their main destination, i.e. the export market $(e=1)$ or local and national consumption $(e=0)$. The focus is on groundwater-based agriculture only, agricultural production that relies on surface water sources is not considered. 
Based on the extensive variables, four flow-fund indicators are calculated. They show how much of a flow element is consumed (or generated) per unit of fund element, and allow the comparison across levels of analysis, accounting for the size of the system under analysis. Specifically, the following indicators are calculated: First, the water use rate $\left(\mathrm{m}^{3} / \mathrm{h}\right)$, i.e. the volume of groundwater used per h of human activity. At the crop level, this is the volume of irrigation water used per h of human activity. Second, the water use density $\left(\mathrm{m}^{3} / \mathrm{ha}\right)$ which indicates the volume of water used per ha of land use. Third, the value added per h (Peruvian Nuevos Soles (PEN)/h) and fourth, the value added per ha (PEN/ha). Lastly, one flow-flow indicator, the economic water productivity $\left(\mathrm{PEN} / \mathrm{m}^{3}\right)$ is calculated which measures the amount of value added generated per unit of groundwater input and one fund-fund indicator indicating the human activity per ha of land use (h/ha).

Two scenarios leading to a sustainable level of groundwater extraction are run by changing the land use per crop $\left(\lambda_{i}\right)$. This subsequently leads to changes in absolute groundwater use, employment and value added, and the related metabolic indicators. A reduction in groundwater use would necessarily lead to considerable economic losses and less employment. However, in case of continued groundwater depletion, socio-economic benefits would be zero once the water resources are depleted whereas socio-economic benefits can theoretically be infinite if sustainable extraction rates are respected. To include this aspect a dynamic component is added to the scenario analysis with MuSIASEM. First, the period that groundwater exploitation under current rates could hypothetically continue $(T)$ is estimated using different estimates of aquifer volume, a volume of annual aquifer recharge of $252 \mathrm{hm}^{3}$ (ANA, 2012a), and our own estimation of the current level of annual groundwater use. Then the present value of the annual gross value added (GVA) is calculated:

$$
P V=\sum_{i=1}^{T} G V A_{i} /(1+r)^{i}
$$

where $T$ indicates the years until the groundwater is depleted and $r$ the social discount rate. This allows us to compare the economic impact of different scenarios over time.

\section{Data}

Data from three different sources as listed in Table 2 are combined, and bottom-up information i.e. unitary production characteristics per ha - is linked with top-down data - i.e. aggregated data for higher economic compartments. All data refer to a time period of one year. First, a dataset from the AAA (Autoridad Administrativa de Agua) Cháparra-Chincha, the local administrative branch of the ANA is used. Data have been collected from 2012 to 2014 within the framework of the Management plan of the aquifers of the Ica valley and the pampas of Villacuri and Lanchas (ANA, 2015). Among 
others the dataset includes producer-level information on land use, groundwater use and irrigation methods, and aggregated data on the groundwater use per economic compartment. Second, crop-level data on profit and labour input per ha of land use have been obtained from Agrobanco, the public agricultural development bank of Peru. Values are benchmarks for the Ica region used for risk assessment of credit proposals. Most clients of the bank are small and medium-size farmers with a possibly different profit and labour intensity per ha compared to large-scale operations. Nonetheless, accounting methods are consistent across crops and the obtained data are the best available proxy. Labour cost and the cost of interest, amortization, depreciation and taxes are added to the profit to align bottom-up data on crop-level added value with top-down information on the GVA at higher levels of analysis. While GVA from the National Accounts is defined as the value of output produced minus the value of intermediate consumption and includes employee cost, profit per crop is defined as the turnover minus the cost of sales and labor at the field level during one year of crop maintenance. Man days per crop and year refer to crop management activities during the productive stage of plantations and include - depending on the type of crop - sewing, pruning, fertilization, the application of agrochemicals, irrigation, harvesting and supervision. The average cost per man day in agriculture is assumed to be $35 \mathrm{PEN}$ in 2015 based on information from the Agrarian Office in Ica. The cost of interest, amortization, depreciation and taxes is assumed to be $30 \%$ of the profit to reach the value of GVA at level n-2. Third, top-down data is provided by the National Statistics Institute (INEI) on GVA generation, population and employment in different economic compartments in the Ica province. GVA is not available at the province level, thus the departmental GVA per capita is used to estimate the provincial GVA. The conversion of man days to h of human activity for the agricultural sector is based on Schuster and Maertens (2016) who find an average of $8.27 \mathrm{~h} / \mathrm{d}$ in horticultural export companies in the Peruvian coastal area. For the rest of the paid work sector, the number of economically active people is converted into working hours based on the legally defined maximum working hours (48 $\mathrm{h}$ /week) and 30 days of annual vacation. The hours of the household compartment are calculated based on the population in the province minus the time spent for paid work. The accounting of human activity is done in $\mathrm{h}$ in order to allow for a simultaneous comparison of indicators across hierarchical levels, e.g. the whole provincial society, economic sectors, households and crops. 
Table 2: Description of data

\begin{tabular}{lllll}
\hline Data & Note & Reference year & $\begin{array}{l}\text { Reference } \\
\text { area }\end{array}$ & Source \\
\hline \multicolumn{2}{l}{ Crop-level data (per ha) } & & & \\
Land use & Groundwater-irrigated land & $2012-2014$ & Province & ANA, 2015 \\
Groundwater & Irrigation water use & $2012-2014$ & Province & ANA, 2015 \\
Labour & Man days & 2015 & Province & Agrobanco \\
Value added & Profit + labour cost & 2015 & Province & Agrobanco \\
Higher-level data (per economic sector) & & & \\
Water use & Groundwater extraction & $2012-2014$ & Province & ANA, 2015 \\
Labour & Economically active population & 2014 & Province & INEI/ENAHO \\
GVA & Gross value added & 2014 & Department & INEI \\
\hline
\end{tabular}

For calculating the present value of GVA for the baseline scenario, different estimates of the years until the aquifer is depleted $(T)$ are used while keeping extraction rates constant. For the scenarios a time span $T$ of 50 and 100 years is assumed. This is in line with the time horizon proposed by Gleeson et al. (2010) who state that multigenerational sustainability goals for groundwater quality and quantity must be set. $T$ for the baseline scenario is calculated based on three estimates of current aquifer volumes as summarized in Bayer (2009) (i.e., (i) $650 \mathrm{hm}^{3}$, (ii) $1,592 \mathrm{hm}^{3}$, (iii) 3,759 $\mathrm{hm}^{3}$ ), an annual recharge of $252 \mathrm{hm}^{3}$ (ANA, 2012a), and our estimation of the current level of annual groundwater use. Different social discount rates $r$ are used, spanning from $1 \%$ to $10 \%$ based on estimates for Peru of Lopez (2008) and Adrogué et al. (2014).

\section{Results}

\subsection{The contribution of agricultural groundwater extraction to socio-economic development}

Table 3 shows the allocation of funds and flows to local and export agriculture relying on groundwater extraction. In the Ica province, 29,531 ha are irrigated with groundwater. This corresponds to two thirds of the total agricultural land use, the rest is irrigated using surface water. More than 24,000 ha of the groundwater-irrigated land are used for cultivating export crops and around 5,000 ha for producing crops for the local market. Water extraction from the aquifer can be linked to more than 51 M hours of agricultural employment (around 35,000 jobs), of which 87\% are for export production. This includes employment in the processing and packaging plants, accounting for $14 \%$ of the human activity in the export sector. The largest share of value added - 90\% - is generated by exports. 
Regarding water use, export production extracts $85 \%$ of the groundwater in the province. This totals $338 \mathrm{hm}^{3} / y$, more than five times the volume used for the production of local crops.

Table 3: Allocation of groundwater-based funds and flows to local and export agriculture

\begin{tabular}{llrrrrrrrr}
\hline Level & Sector & \multicolumn{2}{c}{ Land use } & \multicolumn{3}{c}{ Human activity } & \multicolumn{2}{c}{ Value added } & \multicolumn{2}{c}{ Groundwater } \\
\hline & & ha & $\mathbf{\%}$ & $\mathbf{1 , 0 0 0 ~ h}$ & $\mathbf{\%}$ & $\mathbf{1 , 0 0 0} \mathbf{P E N}$ & $\mathbf{\%}$ & $\mathbf{h m}^{\mathbf{3}}$ & $\mathbf{\%}$ \\
\hline $\mathrm{n}-2$ & Agriculture & 29,531 & 100 & 51,307 & 100 & 797,520 & 100 & 399 & 100 \\
\hline $\mathrm{n}-3$ & Processing & n.a. & & 6,972 & 14 & 24,174 & 3 & 28 & 8 \\
\hline $\mathrm{n}-4$ & Local & 5,280 & 18 & 6,503 & 13 & 81,947 & 10 & 60 & 15 \\
$\mathrm{n}-4$ & Export & 24,251 & 82 & 44,804 & 87 & 715,573 & 90 & 338 & 85 \\
\hline
\end{tabular}

Note: Processing activities are expressed as percentages of export agriculture.

(Source: Own calculations based on ANA, 2015 and Agrobanco, personal communication 2015)

Most of the agricultural land relying on water from the aquifer is irrigated using advanced irrigation techniques, mainly drip irrigation. The share of technified irrigation differs considerably between local and export crops. Whereas $79 \%$ of the land devoted to local agriculture is irrigated using flood irrigation, $91 \%$ of the land covered with export crops uses advanced irrigation techniques. Examining the contribution of different crops to the total funds and flows of the groundwater-based agricultural system, it becomes clear that two export crops - table grapes and asparagus - are dominant (Table 4). Nearly one third of the land is dedicated to asparagus cultivation and $23 \%$ to table grapes for export. Products for the local and national market (i.e., cotton, fruits and vegetables) are cultivated on $18 \%$ of the land. Regarding human activity it becomes evident that export table grape production is very labour intensive accounting for $39 \%$ of the working time related to groundwater extraction. Per ha, around 350 man days/y are needed. For asparagus cultivation only 120 man days/ha/y are needed. Also processing and packaging activities are important for employment generation. Only $13 \%$ of the human activity that depends on groundwater extraction is linked to local crops. Nearly half of the value added is generated by table grape production. Asparagus accounts for $19 \%$ and export vegetables and fruits for $10 \%$ and $9 \%$, respectively. Local fruits and vegetables generate $11 \%$ of the value added. Regarding the contribution of different crop categories to groundwater extraction it can be seen that asparagus consumes one third and table grapes around one-fifth of the groundwater volume used for agricultural production. Together, these two crops are responsible for $55 \%$ of agricultural groundwater extraction, totalling $220 \mathrm{hm}^{3} / \mathrm{y}$. 
Table 4: Allocation of groundwater-based funds and flows to different crops

\begin{tabular}{|c|c|c|c|c|c|c|c|c|c|}
\hline \multirow[t]{2}{*}{ Level } & \multirow[t]{2}{*}{ Crop } & \multicolumn{2}{|c|}{ Land use } & \multicolumn{2}{|c|}{ Human activity } & \multicolumn{2}{|c|}{ Value added } & \multicolumn{2}{|c|}{ Groundwater } \\
\hline & & ha & $\%$ & $1,000 \mathrm{~h}$ & $\%$ & 1,000 PEN & $\%$ & $\mathbf{h m}^{3}$ & $\%$ \\
\hline$n-2$ & Agriculture & 29,531 & 100 & 51,307 & 100 & 797,520 & 100 & 399 & 100 \\
\hline$n-4$ & Local & & & & & & & & \\
\hline$n-5$ & Cotton & 1,720 & 6 & 1,707 & 3 & 13,418 & 2 & 22 & 6 \\
\hline$n-5$ & Local FV & 1,708 & 6 & 3,326 & 6 & 45,285 & 6 & 19 & 5 \\
\hline$n-5$ & Staple & 1,852 & 6 & 1,470 & 3 & 23,244 & 3 & 20 & 5 \\
\hline$n-4$ & Export & & & & & & & & \\
\hline$n-3$ & Processing & n.a. & & 6,972 & 14 & 24,174 & 3 & 28 & 7 \\
\hline$n-5$ & Asparagus & 8,445 & 29 & 8,381 & 16 & 147,662 & 19 & 131 & 33 \\
\hline$n-5$ & Grapes & 6,877 & 23 & 19,906 & 39 & 377,734 & 47 & 89 & 22 \\
\hline$n-5$ & Exp. veg. & 3,064 & 10 & 3,656 & 7 & 82,340 & 10 & 30 & 8 \\
\hline$n-5$ & Exp. fruits & 4,604 & 16 & 5,209 & 10 & 70,033 & 9 & 49 & 12 \\
\hline$n-5$ & Other exp. & 1,261 & 4 & 680 & 1 & 13,631 & 2 & 12 & 3 \\
\hline
\end{tabular}

(Source: Own calculations based on ANA, 2015 and Agrobanco, personal communication 2015)

\subsection{The metabolic pattern of groundwater-based agriculture}

In Figure 4 the metabolic pattern of the agricultural sector is put into context with the wider socioeconomic system of the Ica province, and it is explored how flows are generated or consumed at different levels of analysis. It is estimated that $424 \mathrm{hm}^{3}$ of groundwater are extracted from the IcaVillacurí aquifer per year. Of this volume, $399 \mathrm{hm}^{3}$ are used by the paid work sector, which includes all official economic activities in the province. Nearly all of this water is used by the agricultural sector, mostly for irrigation and processing of export crops. In contrast, most value added (91\%) is generated by economic activities other than the agricultural sector. There are, however, linkages between agricultural production and other sectors such as for example through input supplies or trade activities that cannot be accounted for in this analysis. On average, the water use rate of agricultural production is $7.77 \mathrm{~m}^{3} / \mathrm{h}$, whereas the rest of the paid work sector consumes only $0.003 \mathrm{~m}^{3} / \mathrm{h}$. The water use rate of local agriculture is higher than that of exports due to the cultivation of crops with lower labour input. The average value added of the paid work compartment is $22.12 \mathrm{PEN} / \mathrm{h}$. Groundwater-based agriculture generates only $15.54 \mathrm{PEN} / \mathrm{h}$, with a slightly higher value added for export production (15.97 PEN/h) and 12.60 PEN/h for local crops. The last indicator included in this graph is the economic water productivity, which is around $20 \mathrm{PEN} / \mathrm{m}^{3}$ for the whole social system. The agricultural sector generates $2 \mathrm{PEN}$ per $\mathrm{m}^{3}$ of groundwater use and the economic water productivity of export crops is $0.77 \mathrm{PEN} / \mathrm{m}^{3}$ higher than the water productivity of local crops. Due to the very low water use rate, 
the economic water productivity of the paid-work* compartment is very high, with more than 8,300 PEN of value added generated per unit of groundwater input.

Figure 4: Societal appropriation of groundwater resources

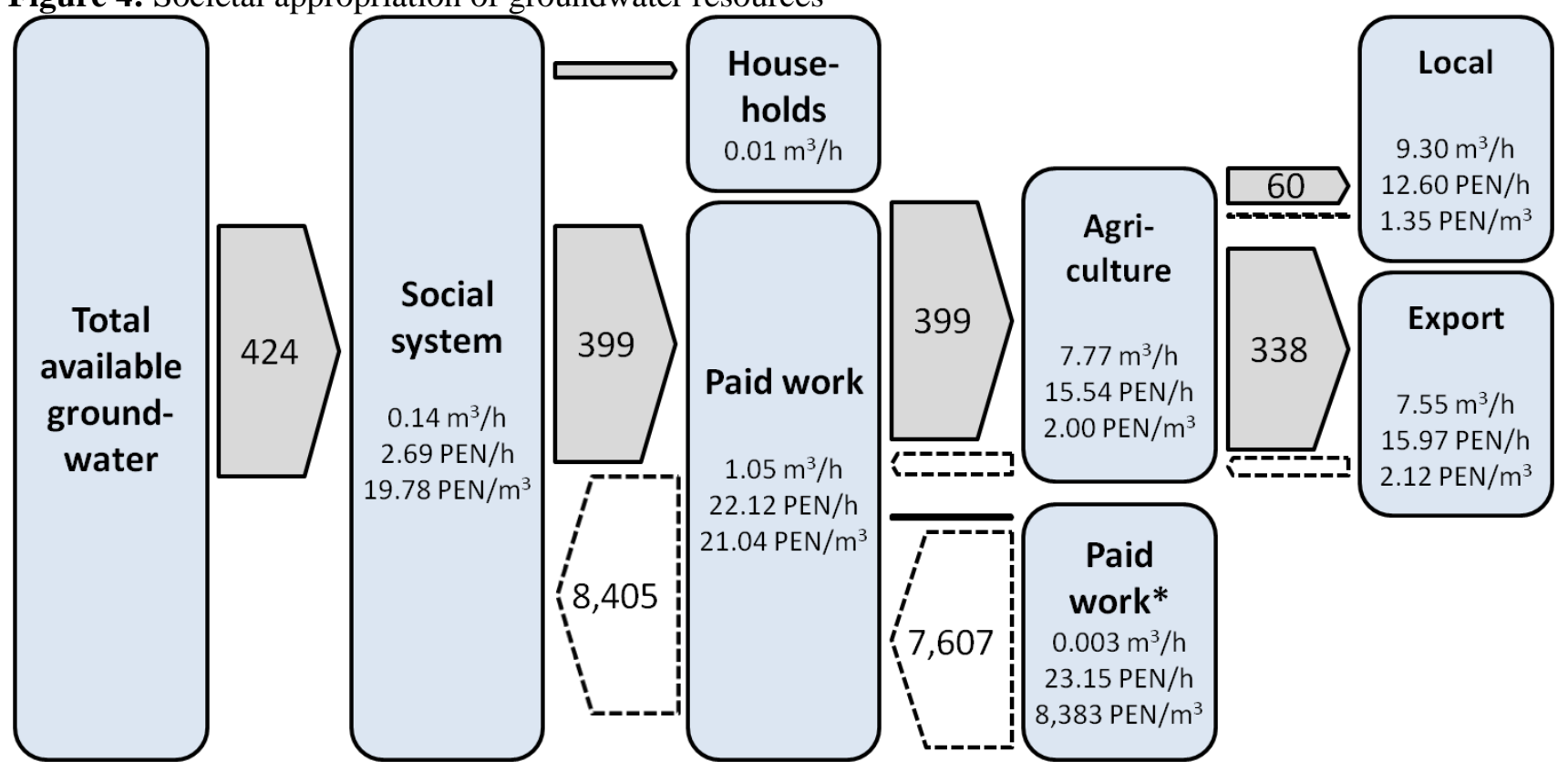

Note: Grey arrows indicate the groundwater flows at the different levels of analysis (in $\mathrm{hm}^{3} / \mathrm{y}$ ). Dashed arrows indicate Gross Value Added (GVA, in M PEN).

(Source: Own calculations based on ANA, 2015, Agrobanco, personal communication 2015 and INEI, 2014)

The metabolic pattern of groundwater-based agriculture at lower scales shows flow-fund indicators, economic water productivity and employment density of different crop categories (Table 5). At this scale of analysis groundwater use, added value generation and human activity can be analyzed per unit of land use. Local agriculture has a higher water use rate, but a lower water use density than exports. This can partly be explained by processing activities of export agriculture which add to water use and employment without occupying agricultural land. In addition, processing plants have a very low water use rate of $3.98 \mathrm{~m}^{3} / \mathrm{h}$; lowering the average water use rate of the export sector. Similarly, table grape production only consumes $4.46 \mathrm{~m}^{3} / \mathrm{h}$ due to high labour input per ha. At the same time, grapes are among the crops with the highest water use density, nearly $13,000 \mathrm{~m}^{3} / \mathrm{ha}$. Asparagus, the figurehead of the export boom in Ica, consumes the highest volume of irrigation water per ha - around $15,000 \mathrm{~m}^{3} / \mathrm{ha}$. Among the local crops, fruits and vegetables perform well with a water use rate of $5.58 \mathrm{~m}^{3} / \mathrm{h}$. Water use density of local crop production lies between $10,783 \mathrm{~m}^{3} / \mathrm{ha}$ for staples and $12,767 \mathrm{~m}^{3} /$ ha for cotton. 
When including economic aspects in the analysis, an important trade-off between groundwater use and value added generation of local and export agriculture becomes evident: The former uses $18 \%$ less irrigation water per ha than the latter but also generates only half of the added value per ha. Table grapes perform outstandingly well, with a value added of nearly $19 \mathrm{PEN} / \mathrm{h}$ and approximately 55,000 PEN/ha; more than twice the amount of export vegetables, the category with the second highest value added. Besides table grapes, local fruits and vegetables have an overall good metabolic pattern regarding water and value added, with a relatively low water use rate and water use density, and high economic gains per unit of land use. On the contrary, cotton production in the Ica province consumes high volumes of groundwater and contributes only marginally to value added.

Table 5: The metabolic pattern of local and export agriculture

\begin{tabular}{|c|c|c|c|c|c|c|c|}
\hline \multirow[t]{2}{*}{ Level } & \multirow[t]{2}{*}{ Sector } & \multirow{2}{*}{$\begin{array}{r}\begin{array}{r}\text { Water } \\
\text { use rate }\end{array} \\
\mathrm{m}^{3} / \mathrm{h}\end{array}$} & \multirow{2}{*}{$\begin{array}{r}\begin{array}{r}\text { Water use } \\
\text { density }\end{array} \\
\mathrm{m}^{3} / \mathrm{ha}\end{array}$} & \multicolumn{2}{|c|}{ Value added } & \multirow{2}{*}{$\begin{array}{r}\begin{array}{r}\text { Econ. water } \\
\text { productivity }\end{array} \\
\mathrm{PEN} / \mathrm{m}^{3}\end{array}$} & \multirow{2}{*}{$\begin{array}{c}\begin{array}{r}\text { Employment } \\
\text { density }\end{array} \\
\mathrm{h} / \mathrm{ha}\end{array}$} \\
\hline & & & & $\mathrm{PEN} / \mathrm{h}$ & PEN/ha & & \\
\hline$n-2$ & Agriculture & 7.77 & 13,497 & 15.54 & 27,007 & 2.00 & 1,737 \\
\hline$n-4$ & Local & 9.30 & 11,458 & 12.60 & 15,522 & 1.35 & 1,232 \\
\hline$n-5$ & Cotton & 12.86 & 12,767 & 7.86 & 7,800 & 0.61 & 992 \\
\hline$n-5$ & Local FV & 5.58 & 10,870 & 13.62 & 26,524 & 2.44 & 1,948 \\
\hline$n-5$ & Staple & 13.59 & 10,783 & 15.82 & 12,551 & 1.16 & 794 \\
\hline$n-4$ & Export & 7.55 & 13,941 & 15.97 & 29,507 & 2.12 & 1,848 \\
\hline$n-3$ & Processing & 3.98 & n.a. & 3.47 & n.a. & 0.87 & n.a. \\
\hline$n-5$ & Asparagus & 15.62 & 15,501 & 17.62 & 17,485 & 1.13 & 992 \\
\hline$n-5$ & Grapes & 4.46 & 12,895 & 18.98 & 54,925 & 4.26 & 2,895 \\
\hline$n-5$ & Export vegetables & 8.22 & 9,806 & 22.52 & 26,874 & 2.74 & 1,193 \\
\hline$n-5$ & Export fruits & 9.41 & 10,650 & 13.44 & 15,213 & 1.43 & 1,132 \\
\hline$n-5$ & Other exports & 17.18 & 9,270 & 20.04 & 10,808 & 1.17 & 539 \\
\hline
\end{tabular}

Note: FV: Fruits and vegetables.

(Source: Own calculations based on ANA, 2015 and Agrobanco, personal communication 2015)

Combining the information about current annual gross groundwater use $\left(424 \mathrm{hm}^{3}\right)$ with the sustainable volume of groundwater exploitation $\left(252 \mathrm{hm}^{3} / \mathrm{y}\right)$ an overexploitation of $172 \mathrm{hm}^{3} / \mathrm{y}$ becomes evident. This equals the volume of 68,800 Olympic swimming pools. It follows that water extraction greatly surpasses aquifer recharge and that the metabolic pattern of groundwater use in the Ica province is not feasible in the long run. Ninety-four percent of the annual gross exploitation are linked to agricultural activities. Given the negligible volume of groundwater used by other economic sectors (less than $1 \mathrm{hm}^{3} / \mathrm{y}$ ) and assuming that water use for the household sector cannot be reduced, it becomes clear that a reduction of groundwater exploitation must stem from the agricultural sector. 


\subsection{Scenarios}

Two scenarios are run to estimate the impact of a land use change with the goal of reducing aquifer depletion on employment and value added. The scenarios are based on the local versus global discourse in the Ica province and entail two conflicting views. First, a reduction of export production which has been condemned for being responsible for groundwater overexploitation due to the conversion of deserts into agricultural land. This scenario is called localism. To reduce groundwater extraction to $252 \mathrm{hm}^{3} / \mathrm{y}$ export production would need to be reduced by $51 \%$, while keeping the scale of local production stable. This would lead to an agricultural land use of 17,163 ha of which 11,883 ha would be used for export crop cultivation. The current crop mix, i.e. the percentage composition of export production is kept constant. Second, a globalism scenario entailing a shift towards the exclusive use of scarce groundwater resources for producing export crops. The rationale behind this scenario is the argument that export production is considerably more water-efficient while having a higher contribution to value added generation and employment than domestic agriculture. Cultivation of crops for auto-consumption and the national markets would need to rely on surface water. Still, it would be necessary to reduce the land use by $33 \%$ - to 16,248 ha - to achieve a sustainable rate of groundwater exploitation. The current crop mix is kept constant. For both scenarios it is assumed that workers who will lose their jobs due to the reduction in agricultural production will be unemployed, i.e. their working hours will shift to the $\mathrm{HH}$ sector. Moreover, due to a lack of data it is assumed that no changes occur in the $\mathrm{PW}^{*}$ sector.

The scenarios are in line with the goal set out in the Management plan of the aquifers of the Ica valley and the pampas of Villacuri and Lanchas: to reduce groundwater extraction through a change of land use while considering market demands (ANA, 2012a). In theory, any land use scenario could be assessed using the MuSIASEM system of accounting and our data. As there is no information on concrete future land uses and any assumption on land use changes would be arbitrary, the current crop mix is kept constant and only the impact of changes in the scale of agricultural production is assessed.

Table 6 summarizes the results of the simulation for the social system (n), the paid work sector (n1) and agriculture (n-2). At level $n$ and $n-1$ both scenarios have similar impacts compared to the baseline. A reduction of size of the agricultural sector leads to a lower water use rate of society, both at provincial level and for the paid work compartment. Added value generation per hour would also decrease at both levels while economic water productivity would increase tremendously. This can be attributed to lower water use rates of the $\mathrm{PW}^{*}$ sector. For the agricultural sector (n-2) the scenarios have opposite impacts on the metabolic indicators compared to the baseline. The water use rate would 
slightly increase for the localism scenario whereas it would decrease when only producing export crops with groundwater resources. In contrast, increasing the share of local crop production would decrease the water use density by $323 \mathrm{~m}^{3} / \mathrm{ha}$. The globalism scenario would increase water use density by 444 $\mathrm{m}^{3} / \mathrm{ha}$. Also, added value per hour and per ha would increase when only producing exports with groundwater; it would decrease when implementing a local crop strategy. Due to the reduction in agricultural land, both scenarios would lead to a tremendous reduction in annual value added and employment. These impacts would be higher for the localism case, where value added would be nearly halved and human activity would be reduced by $44.5 \%$, equalling more than 14,000 jobs.

Table 6: The metabolic pattern of groundwater use based on two land use scenarios

\begin{tabular}{|c|c|c|c|c|c|c|}
\hline Indicator & Unit & Baseline & \multicolumn{2}{|c|}{ Localism } & \multicolumn{2}{|c|}{ Globalism } \\
\hline \multicolumn{7}{|l|}{ Social system (n) } \\
\hline Water use rate & $\mathrm{m}^{3} / \mathrm{h}$ & 0.14 & & 0.08 & & 0.08 \\
\hline Added value & $\mathrm{PEN} / \mathrm{h}$ & 2.69 & & 2.59 & & 2.60 \\
\hline Economic water productivity & $\mathrm{PEN} / \mathrm{m}^{3}$ & 19.83 & & 31.96 & & 32.10 \\
\hline \multicolumn{7}{|l|}{ Paid work (n-1) } \\
\hline Water use rate & $\mathrm{m}^{3} / \mathrm{h}$ & 1.05 & & 0.64 & & 0.63 \\
\hline Added value & $\mathrm{PEN} / \mathrm{h}$ & 22.12 & & 22.51 & & 22.55 \\
\hline Economic water productivity & $\mathrm{PEN} / \mathrm{m}^{3}$ & 21.04 & & 35.41 & & 35.56 \\
\hline \multicolumn{7}{|l|}{ Agriculture (n-2) } \\
\hline Water use rate & $\mathrm{m}^{3} / \mathrm{h}$ & 7.77 & 7.95 & $(+2.3)$ & 7.55 & $(-2.8)$ \\
\hline Water use density & $\mathrm{m}^{3} / \mathrm{ha}$ & 13,497 & 13,174 & $(-2.4)$ & 13,941 & $(+3.3)$ \\
\hline Value added (per h) & $\mathrm{PEN} / \mathrm{h}$ & 15.54 & 15.20 & $(-2.2)$ & 15.97 & $(+2.8)$ \\
\hline Value added (per ha) & $\mathrm{PEN} / \mathrm{ha}$ & 27,007 & 25,205 & $(-6.7)$ & 29,507 & $(+9.3)$ \\
\hline Economic water productivity & $\mathrm{PEN} / \mathrm{m}^{3}$ & 2.00 & 1.91 & $(-4.5)$ & 2.12 & $(+6.0)$ \\
\hline Total value added & $1,000 \mathrm{PEN}$ & 797,520 & 432,578 & $(-47.8)$ & 479,434 & $(-39.9)$ \\
\hline Employment & $1,000 \mathrm{~h}$ & 51,307 & 28,457 & $(-44.5)$ & 30,019 & $(-41.5)$ \\
\hline
\end{tabular}

Note: Values in brackets indicate the percentage change compared to the baseline.

(Source: Own calculations based on ANA, 2015 and Agrobanco, personal communication 2015)

The above shown results are static and show how the metabolism of the current system would change as a response to land use changes. Losses in annual value added and employment would be large compared to the baseline. However, the system would totally collapse once the aquifer is depleted and current socio-economic benefits in the baseline might not compensate for future losses. To this end the present value of annual flows of value added is calculated using formula (2) described above. For the scenarios it is assumed that the current system will continue for 50 or 100 years, respectively. For the baseline it has been calculated that the aquifer will be depleted within three, nine, or 21 years. The approach does not take into account that value added decreases the higher the marginal cost of 
water extraction, but serves the purpose of illustrating the impacts of the scenarios and the baseline taking into account different time spans. Results are shown in Table 7. When assuming a social discount rate of $1 \%$, both a switch to the localism or globalism scenario yield a higher present value and would yet be superior options to the current situation. This holds for nearly all scenarios when assuming that the aquifer would be depleted within three or nine years under the baseline scenario. Only under the assumptions of $T=21$ and social discount rates $r>=0.04$ the value added generation exceeds the environmental cost of future aquifer depletion. The most likely assumption for $T$ is, however, nine years and a sustainable rate of groundwater use would not only provide benefits to society during 50 or 100 years as assumed here, but for an indefinite time span. Thus, policies aimed at reducing groundwater extraction might have considerable negative economic impacts in the short run but will pay off when considering long-term impacts.

Table 7: Present value estimation (M PEN) using different estimates of aquifer depletion (T) and discount rates (r)

\begin{tabular}{lrrrrr}
\hline Scenario & $\mathbf{T}$ & $\mathbf{r = 0 . 0 1}$ & $\mathbf{r = 0 . 0 4}$ & $\mathbf{r = 0 . 0 7}$ & $\mathbf{r = 0 . 1}$ \\
Baseline & 3 & 2.3 & 2.2 & 2.1 & 2.0 \\
& 9 & 6.8 & 5.9 & 5.2 & 4.6 \\
Localism & 21 & 15.0 & 11.2 & 8.6 & 6.9 \\
& 50 & 17.0 & 9.3 & 6.0 & 4.3 \\
Globalism & 100 & 27.3 & 10.6 & 6.2 & 4.3 \\
& 50 & 18.8 & 10.3 & 6.6 & 4.8 \\
& 100 & 30.2 & 11.7 & 6.8 & 4.8 \\
\hline
\end{tabular}

(Source: Own calculations)

\section{Discussion}

The results of this study give interesting insights into the interrelations between globalization, groundwater use and socio-economic implications. As observed by Cabello Villarejo and LópezMadrid (2013) for the case of Spain, there is a conflict in the Ica province between socio-economic benefits trough employment generation and economic profitability on the one hand, and the overdraft of natural resources on the other hand. The expansion of agricultural export production has created a system which is highly profitable but totally dependent on the extraction of scarce groundwater.

First, regarding the contribution of groundwater extraction to socio-economic development it has been shown that more than $80 \%$ of the land irrigated with groundwater is dedicated to production for international markets. The shares of employment and value added are even higher, illustrating a disproportionately high contribution of export activities to the regional labour market and the economy. At the same time it is evident that the overexploitation of the Ica-Villacurí aquifer can largely 
be attributed to the size of the export sector. Currently, agro-export production alone uses $338 \mathrm{hm}^{3} / \mathrm{y}$ of groundwater, $86 \mathrm{hm}^{3}$ more than the sustainable rate of annual groundwater extraction. This confirms the view of other authors that a reduction of groundwater use for exports is indispensable for mitigating the depletion of the Ica-Villacurí aquifer (Hepworth et al., 2010). Table grapes and asparagus are the main export crops of the province, together accounting for more than half of the groundwater-irrigated land, human activity and water abstraction, and contributing to $66 \%$ of the value added. This shows an extremely high concentration on a few figurehead products for international markets.

Second, the metabolic pattern of the Ica province has been analysed by assessing the relative intensities of groundwater use, value added and employment for different societal levels, economic compartments and the agricultural sector. The difference between groundwater use and value added between the agricultural sector and other economic activities is striking. While the former is responsible for $94 \%$ of annual water extraction from the aquifer, the latter generates $91 \%$ of the provincial value added. However, due to data limitations, these figures do not take into consideration linkages between agriculture and related sectors, such as for instance marketing activities related to agricultural trade. Comparing the metabolic indicators of export and local agricultural reveals that the former is generally more efficient, generating $28 \%$ more value added per hour of work and nearly twice the value added per ha. Exports also contribute more to employment and use less groundwater per hour but require more water per ha than local crops. These results are largely driven by the large share of table grapes, which perform very well regarding employment and value added generation per ha while relying on high volumes of irrigation water. Irrigation requirements in the Ica province are high compared to other Peruvian regions and internationally, due to its year-round arid and warm climate. For example asparagus production consumes on average $15,500 \mathrm{~m}^{3} / \mathrm{ha}$ in Ica while the blue and green water requirement has been estimated to range between $5,005 \mathrm{~m}^{3} / \mathrm{ha}$ and $15,444 \mathrm{~m}^{3} / \mathrm{ha}$ across Peru (ANA, 2012b). Madrid and Velázquez (2008) calculate a water requirement of asparagus in Andalusia between $4,065 \mathrm{~m}^{3} / \mathrm{ha}$ and $6,152 \mathrm{~m}^{3} / \mathrm{ha}$.

Third, the scenario analysis shows that socio-economic impacts of reducing groundwater use are large when adapting a static view. More than $40 \%$ of agricultural jobs and value added would be lost if a sustainable annual extraction rate were enforced. The picture changes when taking into account long-term impacts and the possible depletion of aquifer resources within the coming years if current extraction rates are continued. Comparing the two scenarios of using the annually available groundwater volume for more local or more export agriculture, respectively, reveals that the latter strategy would have a less severe socio-economic impact. Such a land use change might however have 
considerable implications for regional food security, vulnerability and resilience due to dependence on external demand and reliance on scarce and variable surface water resources for local crop production. Additionally, other environmental impacts such as soil degradation and water pollution through intensive agricultural production practices also need to be considered carefully when issuing recommendations regarding future land use. For example, according to data from the Regional Agrarian Office in Ica, asparagus cultivation uses $670 \mathrm{~kg} / \mathrm{ha}$ of NPK fertilizer, while the application rate for hard yellow corn and beans are $450 \mathrm{~kg} / \mathrm{ha}$ and $120 \mathrm{~kg} / \mathrm{ha}$, respectively. Various assumptions had to be taken for the elaboration of the baseline and the scenario analysis. Especially the assumption that no changes occur in the $\mathrm{PW}^{*}$ compartment when reducing groundwater extraction is very strong. A strong reduction of agricultural production would obviously have repercussions on other economic sectors through spill-over effects such as input production and shifts in employment opportunities. However, it is not possible to measure these effects with the available data.

Generally, there are two complementary strategies for reducing aquifer depletion, supply side measures and demand side measures (Shah et al., 2007). First, regarding supply side measures, surface water supply in Ica could be increased through diverting water from the highlands and the Pisco River towards the Ica province. Such projects are being discussed by farmers and policy makers, but are meeting resistance from the population in the highlands, who fear that they will be deprived of their water resources (Vera, 2015). It is not yet clear when additional water supplies will be available in Ica. Second, demand-side measures generally include groundwater pricing, water rights and withdrawal permits, legal and regulatory control. These measures are however not always easy to implement in a developing country context without strong institutions. In Ica, a ban on the perforation of new wells has been introduced and well owners are asked to put flow meters and officially register their wells. This would help the monitoring of extraction rates and payments for groundwater use, but to date, around three fourth of the wells still remain unlicensed (ANA, 2014). This implies that local water institutions need to be strengthened, for example through increasing staff and improving administrative capacity. One possible tool for regulating groundwater overdraft is the rationing of farm power, which has proven successful in India (Shah et al., 2008). The feasibility of such an approach in Peru would need to be investigated in detail.

Another possibility to decrease groundwater demand is the use of more efficient irrigation technologies. Such a strategy should primarily target small-scale farmers and local crop production which relies mainly on flood irrigation. Ninety-one percent of the groundwater-based export production is already using advanced irrigation techniques (mostly drip irrigation) and some 
companies in the region are experimenting with very modern technologies to save irrigation water, such as pulse irrigation (Vázquez-Rowe et al., 2016). The scope for reducing groundwater use through increasing water productivity is thus largely limited to local agriculture. Moreover, Kenny (2003) states that increasing water use efficiency also leads to a reduction in aquifer recharge through irrigation drainage and that using more efficient irrigation technologies is only a viable strategy if the 'saved' water is not used for expanding irrigated land.

The finding of high economic returns and employment generation at the expense of high water use densities is assumed to also hold for other agricultural export regions along the Peruvian coast and elsewhere. However, aggregate values for local and export agriculture might differ mainly due to differences in the crop mix. While asparagus and table grape production exert a large influence on the metabolic system in the Ica province, prominent export products along the northern coast are for instance mangos and plantain. Moreover, large irrigation projects that bring surface water from the highlands and the Amazon basin to the arid coastal valleys have already been implemented in many areas (Vera, 2015), decreasing the dependence on groundwater resources in these regions.

\section{Conclusion}

In this article it has been assessed how local and export agriculture contribute to the depletion of the Ica-Villacurí aquifer in Peru. Particularly, trade-offs between groundwater use, value added generation and employment have been analyzed at different socio-economic scales, including a detailed crop-level analysis. The results show that export crop production, especially asparagus and table grapes, makes very efficient use of resources and is of outstanding importance for the socioeconomic system of the Ica province. These positive impacts are however based on the unsustainable use of groundwater resources due to the scale of production, threatening the integrity of the ecosystem and economic development in the long-run. A complementary approach of supply and demand-side measures is needed to reduce aquifer depletion. These results are likely to hold also in other major agricultural export regions relying on groundwater resources.

Regarding the methodology it has been shown that MuSIASEM is a valuable tool to combine quantitative data from different sources, including different sustainability aspects and hierarchical levels of analysis. The developed system of accounting provides the opportunity to test the sustainability implications of various land use scenarios and can be a useful tool to inform policy. The framework can be adapted by researchers and policy makers to assess more specific land-use scenarios following a similar procedure as for the localism and globalism scenarios in this article. It is possible 
to specify and adapt the model to other contexts and to include additional variables such as for instance the contribution of different crops to water and soil pollution through fertilization, and energy use. This could be done through a closer collaboration with stakeholders to define possible future land uses and production scenarios. A more detailed analysis of different farm types (as in Gomiero and Giampietro, 2001) could be used for assessing differences between large-scale and smallholder agriculture and to reflect the variety in production systems. Such an approach would however need more tailored data on production coefficients than the data used in this study.

Our analysis yet illustrates the major differences between the sustainability of domestic and export agriculture regarding groundwater use, employment and value added generation, and the metabolic approach used in this study is a promising tool for future research on cross-dimensional sustainability impacts.

\section{Acknowledgements}

The research leading to these results has received funding from the European Union's Seventh Framework Programme for research, technological development and demonstration under grant agreement $\mathrm{n}^{\circ}$ 311778. The authors are very thankful to Eric Rendón Schneir (Universidad Agraria La Molina), Juan Pablo Mariluz Silva from the ANA, Rogélio León Guzman from Agrobanco, the Dirreción Regional Agraria de Ica and Jorge Foronda for support in the data gathering process. We thank Gonzalo Gamboa (Autonomous University of Barcelona) for valuable comments on an earlier version of this article. We are also grateful to Mario Giampietro and his team from ICTA for methodological support. Finally, we thank seminar and conference participants in Leuven and Barcelona, and three anonymous reviewers for useful comments on previous versions of this paper.

\section{References}

Adrogué, C.; Lozano, T.; Maldonado, S. (2014). Social discount rates for public investment projects for conservation and provision of ecosystem services: Estimation for Peru. Working paper, Universidad de San Andrés, Buenos Aires, Argentina.

Aksoy, M.A.; Beghin, J.C. (eds.) (2005). Global Agricultural Trade and Developing Countries. The World Bank: Washington, DC, USA.

ANA (2012a). Plan de gestión de los acuíferos del valle de Ica y pampas de Villacurí y Lanchas. (Management plan of the aquifers of the Ica valley and the pampas of Villacurí and Lanchas)National Water Authority: Lima, Peru. (In Spanish)

ANA (2012b). Huella hídrica del cultivo del espárrago en el Perú. (The water footprint of asparagus in Peru) National Water Authority: Lima, Peru. (In Spanish)

ANA (2014). Recursos hídricos subterráneos en el valle de Ica, pampas de Villacuri y Lanchas. (Groundwater resources in the Ica valley and the pampas of Villacurí and Lanchas). issuu.com/pepelhc/docs/01-ana (accessed on 25 November 2015). (In Spanish) 
ANA (2015). Plan de gestión de los acuíferos del valle de Ica y pampas de Villacurí y Lanchas. Programa $n^{\circ}$ 03. Disminución de los volúmenes de explotación. (Management plan of the aquifers of the Ica valley and the pampas of Villacurí and Lanchas. Program $n^{\circ} 03$. Reduction of exploitation volumes). National Water Authority: Ica, Peru. (In Spanish)

ANA (s.d.). Plan de gestión del acuífero del valle de Ica y pampas de Villacurí y Lanchas. (Management plan of the aquifers if the Ica valley and the pampas of Villacurí and Lanchas) Presentation, $\quad$ www.ana.gob.pe/media/528051/ica\%20-\%20plan\%20de\%20gesti\%C3\%B3n.pdf (accessed on 19 May 2016). (In Spanish)

Bayer, D. (2009). Acuífero de Ica: Reservas, sobre-explotación, y años que puede durar. (The Ica aquifer: Reserves, over exploitation and for how many years it can last) issuu.com/iproga/docs/ica_acuifero_sobre-explotacion_y_an (accessed on 14 April 2016). (In Spanish)

Bellemare, M.F. (2012). As you sow, so shall you reap. The welfare impacts of contract farming. World Development 40(7), 1418-1434.

Cabello Villarejo, V.; López Madrid, C. (2014). Water use in arid rural systems and the integration of water and agricultural policies in Europe: The case of Andarax river basin. Environ Dev Sustain 16, 957-975.

DRA Ica (2014). Serie histórica de los principales cultivos (Time series of the main crops). www.agroica.gob.pe/?q=node/246 (accessed on 14 April 2016). (In Spanish)

Dollar, D.; Kraay, A. (2004). Trade, growth, and poverty. Econ. J., 114, 22-39.

Famiglietti, J.S. (2014). The global groundwater crisis. Nature Climate Change 4, 945-948.

FAO (2015). Faostat database. faostat3.fao.org (accessed on 2 October 2015).

Garavito, C., Muñoz, I. (eds.) (2012). Empleo y protección social (Employment and social protection). Fondo Editorial de la Pontificia Universidad Católica del Perú, Lima, Peru. (In Spanish)

Giampietro, M. (2004). Multi-Scale Integrated Analysis of Agroecosystems. Boca Raton, FL, USA: CRC Press.

Giampietro, M.; Mayumi, K.; Ramos-Martin, J. (2009). Multi-scale integrated analysis of societal and ecosystem metabolism (MuSIASEM): Theoretical concepts and basic rationale. Energy 34, 313-322.

Giampietro, M.; Aspinall, R.J.; Ramos-Martín, J.; Bukkens, S. (eds) (2014). Resource accounting for sustainability assessment. The nexus between energy, food, water and land use. Oxon, New York, USA: Routledge.

Gleeson, T.; VanderSteen, J.; Sophocleous, M.A.; Taniguchi, M.; Alley, W.M.; Allen, D.M.; Zhou, Y. (2010). Groundwater sustainability strategies. Nature Geoscience 3, 378-379.

Gomiero, T.; Giampietro, M. (2001). Multiple-scale integrated analysis of farming systems: The Thuon Lo commune (Vietnamese uplands) case study. Population and Environment: A Journal of Interdisciplinary Studies 22(3), 315-352. 
Hepworth, N.D.; Postigo, J.C.; Guemes Delgado, B.; Kjell, P. (2010). Drop by drop. Understanding the impacts of the UK's water footprint through a case study of Peruvian asparagus. Progressio, CEPES and Water Witness International: London, UK.

Hoekstra, A.Y.; Mekonnen, M.M. (2012). The water footprint of humanity. PNAS 109(9), 3232-3237.

Hoogesteger, J.; Wester, P. (2015). Intensive groundwater use and (in)equity: Processes and governance challenges. Environmental Science \& Policy 51, 117-124.

INEI (2014). Cuentas nacionales. Sistema de información regional para la toma de decisiones (National accounts. Regional information system for decision making). www.inei.gob.pe/sistemasconsulta/ (accessed on 14 April 2016). (In Spanish)

Kenny, E. (2003). The false promise of sustainable pumping rates. Groundwater 41(1), 1-4.

Lopez, H. (2008). The social discount rate: Estimates for nine Latin American countries. Policy research working paper 4639. The World Bank, Washington DC, USA.

MacDonald, G.K.; Brauman, K.A.; Sun, S.; Carlson, K.M.; Cassidy, E.S.; Gerber, J.S.; West, P.C. (2015). Rethinking agricultural trade relationships in an era of globalization. BioScience 65(3), 275289.

Madrid, C.; Velázquez, E. (2008). El metabolismo hídrico y los flujos de agua virtual. Una aplicación al sector hortofrutícola de Andalucía (España) (The water metabolism and virtual water flows. An application to the Andalusian horticultural sector). Revista Iberoamericana de Economía Ecológica 8, 29-47. (In Spanish)Madrid-Lopez, C.; Cadillo-Benalcazar, J.J.; Diaz-Maurin, F.; Kovacic, Z.; SerranoTovar, T.; Gomiero, T.; Giampietro, M.; Aspinall, R.J.; Ramos-Martin, J.; Bukkens, S.G.F. (2014). Punjab state, India. Chapter 13. In: Giampietro, M.; Aspinall, R.J.; Ramos-Martín, J.; Bukkens, S. (eds) (2014). Resource accounting for sustainability assessment. The nexus between energy, food, water and land use. Oxon, New York, USA: Routledge.

Madrid-Lopez, C.; Giampietro, M. (2015). The water metabolism of socio-ecological systems. Reflections and a conceptual framework. Journal of Industrial Ecology 19(5), 853-865.

Maertens, M.; Minten, B.; Swinnen, J.F. (2012). Modern food supply chains and development. Evidence from horticultural export sectors in Sub-Saharan Africa. Dev. Policy Rev. 30, 473-497.

Mekonnen, M.M.; Pahlow, M.; Aldaya, M.M.; Zarate, E.; Hoekstra, A.Y. (2015). Sustainability, efficiency and equitability of water consumption and pollution in Latin America and the Carribean. Sustainability 7, 2086-2112.

MINAGRI, ANA, COSUDE, WWF (2015). Huella hídrica del Perú. Sector agropecuario. (The water footprint of Peru. Agricultural sector) www.ana.gob.pe/media/1256542/estudio\%20huella\%20h\%C3\%ADdrica\%20nacional.pdf (accessed on 14 April 2016). (In Spanish)

Oglethorpe, D. (2010). Optimising economic, environmental, and social objectives: a goalprogramming approach in the food sector. Environment and Planning A 42(5), 1239-1254. 
Oré, T., Bayer, D., Chiong, J., Rendón, E. (2012). Emergencia hídrica y explotación del acuífero en un valle de la costa peruana. El caso de Ica, Perú (Water emergency and exploitation of the aquifer in a coastal valley of Peru. The case of Ica, Peru). Medio Ambiente y Urbanización 77(1), 213-234. (In Spanish)

Schuster, M., Maertens, M. (2016). Do private standards benefit workers in horticultural export supply chains in Peru? Journal of Cleaner Production 112(4), 2392-2406.

Schwarz, J.; Schuster, M.; Annaert, B.; Maertens, M.; Mathijs, E. (2016). Sustainability of global and local food value chains. An empirical comparison of Peruvian and Belgian asparagus. Sustainability 8,344 .

Schwarz, J.; Mathijs, E.; Maertens, M. (2015). Changing patterns of global agri-food trade and the economic efficiency of virtual water flows. Sustainability 7(5), 5542-5563.

Serrano-Tovar, T.; Cadillo-Banalcazar, J.J.; Diaz-Maurin, F.; Kovacic, Z.; Madrid-Lopez, C.; Giampietro, M.; Aspinall, R.; Ramos-Martin, J.; Bukkens, S.G.F. (2014). The republic of Mauritius, Chapter 12. In: Giampietro, M.; Aspinall, R.J.; Ramos-Martín, J.; Bukkens, S. (eds.) (2014). Resource accounting for sustainability assessment. The nexus between energy, food, water and land use. Oxon, New York, USA: Routledge.

Shah, T.; Burke, J.; Villholth, K. (2007). Groundwater: a global assessment of scale and significance. Chapter 10. In: Molden, D. (ed.). Water for food, water for life. A comprehensive assessment of water management in agriculture. Earthscan, London, UK, 395-423.

Shah, T.; Bhatt, S.; Shah, R.K.; Talati, J. (2008). Groundwater governance through electricity supply management: Assessing an innovative intervention in Gujarat, western India. Agricultural Water Management 95, 1233-1242.

Vázquez-Rowe, I., Kahhat, R., Quispe, I., Bentín, M. (2016). Environmental profile of green asparagus production in a hyper-arid zone in coastal Peru. Journal of Cleaner Production 112, 2505-2517.

Velazco, J., Velazco, J. (2012). Características del empleo agrícola en el Perú (Characteristics of agricultural employment in Peru). In: Garavito, C., Muñoz, I. (eds.) (2012). Empleo y protección social (Employment and social protection). Fondo Editorial de la Pontificia Universidad Católica del Perú, Lima, Peru. (In Spanish)

Vera, D.J. (2015). The socio-cultural, institutional and gender aspects of the wáter transferagribusiness model for food and water security. Lessons learned from Peru. Food Sec. 7, 1187-1197.

WWAP (2014). The United Nations World Water Development Report 2014: Water and Energy. Volume 1. UNESCO: Paris, France.

WWAP (2015). The United Nations World Water Development Report 2015: Water for a Sustainable World. UNESCO: Paris, France. 